\title{
Ideational Meaning of Traditional Wedding Ceremony Horja Haroan Boru Tapanuli Selatan
}

\author{
Irma Khoirot Daulay, Amrin Saragih, Rahmad Husein ${ }^{1}$
}

English Applied Linguistic Department, Universitas Negeri Medan

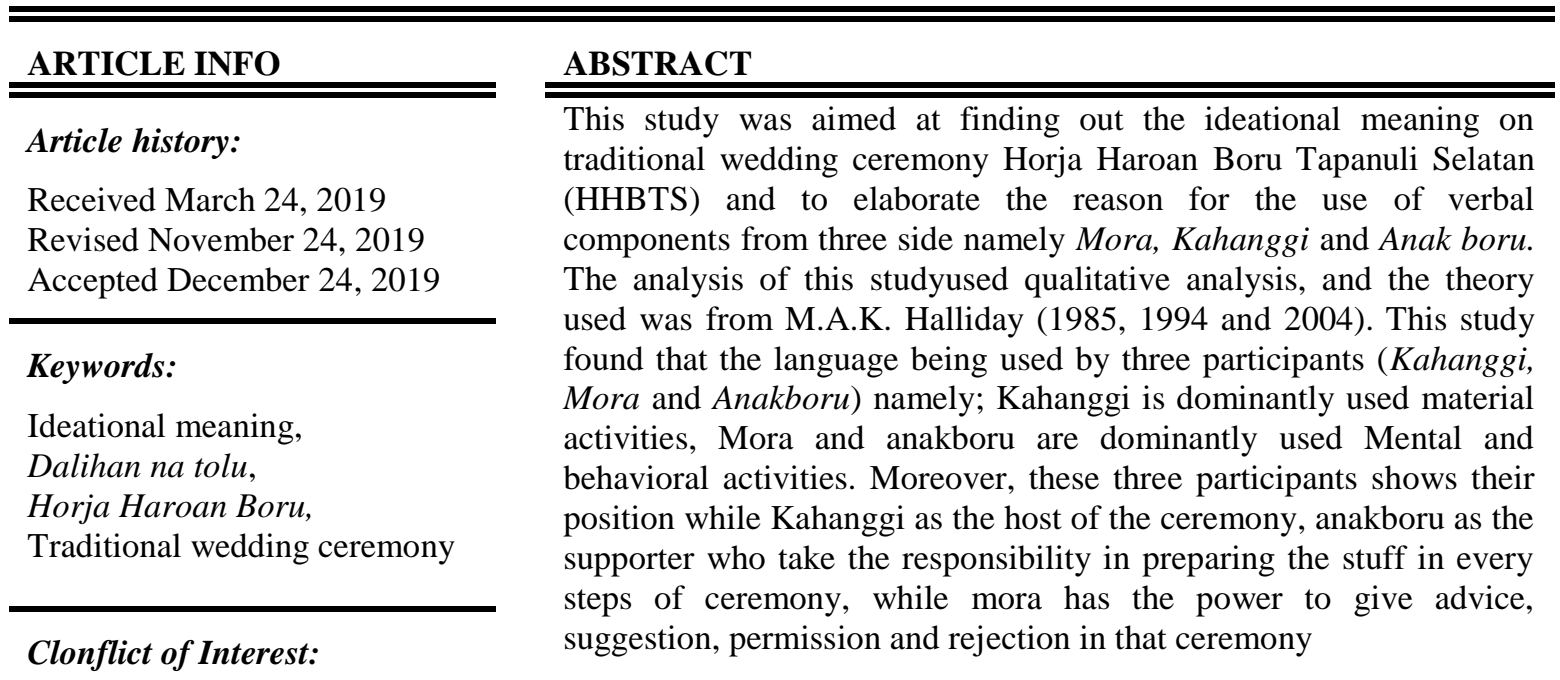

None

Funding:

None

Corresponding Author: Postgraduate School of State University of Medan, Jl. Pasar V Medan Estate, Percut Sei Tuan, Deli Serdang, Sumatera Utara. E-mail: irmakhoirotdaulay@unprimdn.ac.id

\section{Introduction}

\subsection{The Background}

Ideational meaning is one of the tools in linguistics area to analyze what is means behind the text, how the text established and what is the reason to use language in the ways they are. Cultural ceremony as one of the heritage that must be preserved by each society, attracted by everyone to be conducted as the study to keep in touch with nature and to keep it there in our life. The combination of ideational meaning and cultural wedding ceremony of Horja Haroan Boru Tapanuli Selatan brings the new horizon in the linguistics study especially in cultural areas.

Futhermore, there are relevant studies due to this recent one, namely The Role Of Dalihan Na Tolu In Keep The Interreligious Harmony At Balige Distric Toba Samosir Regency and Ideational Meaning Of Wedding Ceremony In Deli Malay's Traditional Culture: Multimodal Analysis. These two studies had been inspired to this recent study; since it is the new area with differ to the previous studies. The Role Of Dalihan $\mathrm{Na}$ Tolu In Keep The Interreligious Harmony At Balige Distric Toba Samosir Regency is about the role in each position of Dalihan $\mathrm{Na}$ Tolu, it is not about the language used by each person except for describing the power of each position in the cultural aspect of Batak Toba, and the other one is and Ideational Meaning Of Wedding Ceremony In Deli Malay’s Traditional Culture: Multimodal Analysis, knows as the analysis in Deli Malay's Traditional Culture. 
Besides that, as the biggest traditional wedding ceremony in Tapanuli Selatan, Horja Haroan Boru has the power since it is contain of Dalihan Na Tolu aspect which is means Dalihan Na Tolu have the active role to conduct this biggest traditional wedding ceremony. It must be different from other traditional ceremony which only conducted by the relative family and not participated as many as the Horja Haroan Boru had. Many participants held this traditional wedding ceremony, and the languages used by each Dalihan $\mathrm{Na}$ Tolu must be different from one to another based on each position. The language differences used by each position in Dalihan Na Tolu contain meaning which is regulated in custom and cannot be arbitrary used by each person. In addition, the regulation of language use by each person in Dalihan Na Tolu attracted to be analyzed to know what is the meaning behind the text, how it is established and what is the reason to use the language in the way they are.

\subsection{The Objectives}

This study aims to find out the ideational meaning on traditional wedding ceremony HHBT and to elaborate the reason for the use of verbal components from three side namely Mora, Kahanggi and Anak boru.

\section{Literature Review}

\subsection{Language and context}

SFL regards context of situation as "the immediate environment in which a text is actually functioning" (Halliday and Hasan, 1985: 46). According to Halliday (1978:142-145), it is reflected in three aspects within a text:

(i) What is language being used to talk about: this is concerned with social action (i.e. what is going on) and is referred to as field in SFL theory.

(ii) Who is taking part in the linguistic interaction and the relationship between the participants? That is the role structure among the participants, known an Tenor.

(iii) What role is language playing in the interaction: this is related to the symbolic organization of text within the immediate environment in which it is functioning and is known as Mode?

These three aspects "determine the range within which meanings are selected and the forms which are used for their expression" (Halliday, 1978: 31). Taken together, they represent the register of text, which is defined as a configuration of semantic resources that the member of a culture typically associates with a situation type (Halliday, 1978:111). The significance of register in SFL theory is that it provides a correlating (semantic) link between changes in language-in-use and variation in situation types on the hand (Halliday and Hasan, 1985: 38), and offers a form of prediction of how a text will unfold within particular situation types on the other (Halliday,1978: 62; Halliday and Hasan, 1985: 46)

Compared to context of situation, context of culture is more general and abstract. As noted, Halliday $(1978: 2)$ characterized culture as an information system in social terms; and the characterization can be explained as follows:

Any actual context of situation, the particular configuration of field, tenor, and mode that has brought a text into being, is not just a random jumble of features but a totality - a package, so to speak, of things on these occasuons and attach these meanings and values to them;nthis is what a culture is (Halliday and Hasan, 1985:46).

On this basic culture can be seen as an overall referential context for language use. Eggins (1994,2004) and Martin 1992: 494) suggest context of culture asa social process, and it is reflected in the genre of texts. According to Martin (1984: 25, cited in Eggins, 2004: 55) genre is "a staged, goal oriented, purposeful activity in which speakers engage as members of a culture". Martin (1985: 248, cited in Eggins, 2004: 55) also suggests genre is related to "how things get done, when language is used to accomplish them". Register is the mediating level between genre and language mediating level between genre and language. As an overarching element, context of culture (genre) is reflected in the register variables of text, namely field, tenor and mode - which in turn are reflected as well as 'encoded' in the linguistic choices that are made in the text. In taking into account the context of situation and context of culture in language-in use, SFL makes the claim that the meanings that are exchanged in texts are non-arbitrary in nature (Halliday, 1978: 44-45; see also Kress, 1993). They are in fact determined and influenced by the social contexts in which acts of communication are situated. SFL thus underscores the significance of social dimensions of communication. With reference to Halliday's (1978: 2) explanation of language as social semiotic ("a context of speech is itself a semiotic contract"), social contexts can be considered as crucial meaning-making elements that underpin communicative acts. Owing to constrains in focus, the analysis of South Tapanuli traditional wedding ceremony is discussed in relation to the semiotic resource and the social construct which functions to construe human experiences and to exchanges interpersonal meanings. 
At the same time and in relation to the register variables of text, SFL theory further expands the notion of meaning. Meanings are not restricted to the representational kinds but also include the social and interpersonal kind s as well as the organizational ones (Halliday, 1973, 1985, 2004). This interpretation of meaning highlights the fact that there are three simultaneous viewpoints from which acts of communication can be explored, and it offers an investigative approach that allows semiotic acts to be examined from different perspectives. More significantly, such a re-defenition of meaning provides an interpretative basis that is applicable to analysis of different forms of communicative acts. To further relate SFL's expanded interpretation of meaning and its potential for considering other forms of communication, the concept of metafunction will be examined.

\section{2. Summary of the SFL approach to language}

In summary, language is seen as a semiotic resource for construing and representing human experiences and for enacting interpersonal relationships. In modeling language as systems of meaning potential, choice becomes the basis for language use. Not only is language in-use or text shaped by choice, it is also influenced by social contexts namely context of situation and context of culture. Such social commixes are in turn reflected in the register variables (field, tenor, and mode) and the genre of the texts. Of particular significance between language as systems of choice and social contexts is the emphasis on the nonarbitrariness of meaning; that is, meaning are realized through selections as well as orderings of semiotic choices, which in turn are determined by the social contexts of the communication. In short, in SFL theory text is conceived of as a social construct.

At the same time, SFL theory proposes a metafunction view of language, where language consists of three functional components: ideational, interpersonal, and textual. This metafunctional perspective of language can be extended to the exploration of other types of communication, opening up the potential to examine other semiotic texts such as in the wedding ceremony in terms of not just of 'what' they mean, but 'how' they mean and 'who' is involved (as well as 'how' they interact) in the exchange of meanings

\subsection{Metafunction}

As already noted, a principle idea that underlies SFL is its conception of language as social semiotic. That is language is a system of meaning potentials for construing human experiences and for exchanging meanings in interpersonal contexts (Halliday, 1985, 1994, 2004). Language is seen as a semiotic system that is multi-functional in nature. At the most basic level, ther are three functional components in language, which are termed metafunction (Halliday, 1985, 1994, 2004) within SFL theory and can be considered as 'macrofunctions', that is as the most general categories of meaning potential that are common or intrinsic to all use of language (Halliday, 2004: 29-31). The three metafunctions are:

(i) a. Ideational metafunction classified into experiential function and logical function. The ideational metafunction is concerned with representing human experiences of both external world as well as the internal consciousness of individuals known as the experiential function and organizing the represented experiences into a logical whole known as logical function.

In terms of the register of text, the ideational metafunction is reflected in the field. The semantic choices of this metafunction are realized in language through the grammatical system of transitivity which include specific sets of choices, as the representation patterns of experiences, conceptualized as situation types with the following components: a process, realized by a verb, the participants involved typically they represent persons, things or abstract entities, the attributes ascribed to them which typically characterize, identify, or locate the participants and finally the circumstancesof place, time, manner, etc. attendant to the process itself (Downing and Locke, 2002: 110-113).

With regard to the logical relationship of experiences, the relationship represents the way the speaker or writer sees the connections to be made between one clause and another. Such connections do not simply link clauses within a clause complex but also clauses within a paragraph and paragraphs by using connectors. The relationship of experience within a text is realized in language through the grammatical system of logicosemantic relation classified into expansion by which a situation is expanded by means of other situations and projection by which a situation is projected through a verb saying or thinking (Downing and Locke, 2002: 279). Expansion is concerned with a tighter integration of meaning at the clause level of language (Halliday, 2004: 365) specifically between primary and secondary clauses. This type of logical-semantic relation can be realized by one of these three choices: (a) elaboration, which is about how a clause further elaborates the meaning of another clause by further specifying or describing it (Halliday, 2004: 396); (b) extension, which is concerned with how one clause extends the meaning of another by adding something new to it (Halliday, 2004: 405); and (c) enhancement, in which a clause enhances the meaning of another by further "qualifying it in one of a number of possible ways: by reference to time, place, manner, cause or condition" (Halliday, 2004: 410). 
Expansion, like all logical relations is semantic in nature, and realization of expansion are not necessarily restricted by structural relations in texts (Halliday, 2004: 369). Even though the idea of expansion is developed for language, the fundamental semiotic principles that are embodied in it can be extended to other semiotic resources, such as the objects and the activities in the ceremony constructed as an integral as an integral resource.

\section{Method}

This study used qualitativemethod to analyze and to discover the meaning and the reason behind the use of the language by Dalihan Na Tolu. The qualitative method was supported in finding and completing this study. Moreover, the data needed by this study were the text, the interview data and video of the event to support the whole evidence in completing the study.

The subject of this study are Mora, Kahanggi and Anak Boru or known as Dalihan Na Tolu from the wedding of Rahmad Halomoan Srg, ST. and Nurhaisyah, F Lubis, S.Pd which held on Saturday until Sunday, on October, the 20th and 21st 2018. Data refer to the rough materials collected from the world to be studied including interview transcripts, observation field notes, diaries, photographs, official documents, newspapers articles (Bogdan and Biklen, 1981: 106). The subjects of the research are the participants of Dalihan Na Tolu in Traditional Ceremony of Horja Haroan Boru and the informants to be interviewed as additional data.

From Mora is Muhammad Effendi Harahap designation as Sutan Baginda Guru Harahap, Kahanggi is Awaluddin Simamora designation as Baginda Hormat Simamora, and anak boru is H. Burhanuddin Hasibuan, S.Ag designation as Tongku Sodongoron Hasibuan. Whereas, The Object of the research are the verbal and visual components of semiosis in HHBT in Traditional Ceremony of HHBT and interview transcripts and observation field notes.

The technique of collecting data were collecting the data are from library research, artifacts and observation, after that make sure to complete all the data needed and analyze it by using ideational meaning of metafunction analysis the last summarize the whole data into finding and conclusion of Traditional Ceremony of Horja Haroan Boru Tapanuli Selatan.

\section{Result and Discussion}

The data of this study were the verbal components occurred in traditional wedding ceremony of HHBT. The verbal analysis were analyzed from the three speakers namely Mora, Kahanggi and Anakboru. based on those speakers, the verbal analysis were divided into three aspects such as process, participants and circumstances as the content in finding the ideational meaning from the data. After analyzing the data, the analysis was described into words and related into social aspect to elaborate the reason of using those kinds of words.

Summary of process on verbal components in traditional wedding ceremony of HHBT, Kahanggi got, $40 \%$ for Material, $5 \%$ for Mental, 30\% for Behavioral, 20\% for Verbal and 5\% for Existential. Mora got $20 \%$ for Material, 30\% for Mental, 30\% for Behavioral, 5\% for identification, 5\% for Verbal, and $10 \%$ for Existential, and Anak Boru got 5\% for Material, 40\% for Mental, 35\% for Behavioral, 5\% for Relational, and $15 \%$ for Verbal.

Summary of participants on verbal components in traditional wedding ceremony of HHBT, in Kahanggi, The Brides / The Broom got 15\%, Mora got 32\% , Kahanggi got 10\%, Anak Brou got $10 \%$, Raja got 10\%, Hatobangon 32\% and Pisang Raut got 3\%. In Mora, The Brides / The Broom got 15\%, Mora got $10 \%$, Kahanggi got 45\%, Anak Boru got 5\%, Raja got 22\%, Hatobangon 10\% and Pisang Raut got $3 \%$. The last in Anak Boru, The Brides / The Broom got 15\%, Mora got 16\%, Kahanggi got 29\%, Anak Boru got $5 \%$, Raja got $22 \%$, Hatobangon $10 \%$ and Pisang Raut got $3 \%$.

Summary of circumstances on verbal components in traditional wedding ceremony of HHBT in Kahanggi, Location occurred 80\%, and Contingency 20\%. In Mora, Location occurred 90\%, and Contingency 10\%. In Anak Boru, Location occurred 95\%, and Contingency 5\%. For the clear explanation of the summary, it is attached in the appendix of this journal.

In summary, the Kahanggi is dominantly imposing material activities to the three participants (Hatobangon, Mora and Anakboru). the weighty is in order of Hatobangon, Mora and Anakboru. the priority gives to Hatobangon and Mora is to pay respect to the elder and the rest Anakboru is in the rest.

Additionally, the mora is dominantly imposing Mental and Behavioral activities to the Kahanggi and Raja. The weighty is in order to Kahanggi as the host in the ceremony, while the priority gives to Raja is to pay respect to the king of the ceremony.

The last, Anakboru is dominantly imposing mental and behavioral activities to the three participants (Kahanggi, Raja and Mora). The weighty is in order to Kahanggi as the host in the ceremony, while the priority gives to Raja and Mora are to pay respect to the king of the ceremony. 
Moreover, the circumances occurred on the two aspects are location and contingency. It means the other aspects of circumtances such as extent, manner, cause, accompaniment, role, matter and angle did not occurred in this ceremony.

\section{Conclusion}

After all the analysis, it can be concluded that the language being use by three participants (Kahanggi, Mora and Anakboru)namely; Kahanggi is dominantly used material activities, Mora and anakboru are dominantly used Mental and behavioral activities. Moreover, these three participants shows their position while Kahanggi as the host of the ceremony, anakboru as the supporter who take the responsibility in preparing the stuff in every steps of ceremony, while mora has the power to give advice, suggestion, permission and rejection in that ceremony.

\section{References}

Al Furqan. (2016). Traditional Mariage in Pauh, Padang, West Sumatera.Al-Ta'lim Journal UIN Padang Vol.23 No.1. Retrieved from http://journal.tarbiyahiainib.ac.id/index.php/attalim/article/view/166.

Al-Zubaidi. N. A. G. (2017). Wedding Invitation Genre: Communicating Sociocultural Identities of Iraqi Society. Lublin Studies In Modern Languages And Literature (Online) Vol. 41(1). Retrieved from https://journals.umcs.pl/lsmll/article/view/4012.

Ariady. K \& Sumarsih. (2014).Theme And Rheme In "Pepongoten" At Gayo Wedding Ceremony. LINGUISTICA Journal of Linguistics of FBS UNIMED. Vol. 3 No.1. Retrieved from http://jurnal.unimed.ac.id/2012/index.php/jalu/article/view/1221.

Arniati. M. I Gede Budasi.. I. G \& Ramendra. D. P. (2013). An Analysis of Communication Strategies Used In Ngidih Wedding Ceremony In Sawan Village. Jurnal Pendidikan Bahasa Inggris UNDIKHSHA. Vol.1No.1. Retrieved from https://ejournal.undiksha.ac.id/index.php/JPBI/article/view/5285.

Ary. D, Jacobs.L C \& Sorensen CK.(2009).Introduction to Research Education $8^{\text {th }}$ Edition. Wadsworth Cengage Learning. USA

Cerulo. K.A . (2002). Culture in Mind.London: Continuum.

Eggins. S. (2004). An Introduction to Systemic Functional Linguistics, (2 $\left.{ }^{\text {nd }} \mathrm{ed}\right)$. London: Continuum.

Fairclough, N.(1999).Critical Discourse Analyisis. Edinburgh: Pearson

Education.

Nasution, Pandapotan.(2012).Horja Pabuat Boru. Medan: Yayasan Pencerahan Mandailing

Faramarzi.S., Elekaei, A. \& Tabrizi, H.H. (2015).Genre-based Discourse Analysis of Wedding Invitation Cards in Iran. Journal of Language Teaching and Research, Vol. 6, No. 3 Retrieved from http://dx.doi.org/10.17507/jltr.0603.25

Halim. A .(2013).Figures Of Speech Of Ngekhane In Alas Wedding Ceremony. Jurnal Pendidikan TABULARASA. Vol.10 No.2 Retrieved from http://jurnal.unimed.ac.id/2012/index. php/tabularasa.

Halliday, M.A.K. (1985).An Introduction to Functional Grammar.London: Edward Arnold

Halliday, M.A.K.\& Hasan R. (1985).Language, context and text; Aspects Of Language In A Social Semiotic Perspective. Melbourne. Deakin University.

Halliday, M.A.K. \& Martin J.R. (1993).Writing Science: Literacy and Piscoursive Power, Pittsburgh: University of Pittsburg.

Halliday, M.A.K. (1994).An Introduction to Functional Grammar ( ${ }^{\text {nd }}$ ed).London: Edward Arnold.

Halliday, M.A.K.\& Matthiessen. (2004).An Introduction to Functional Grammar $\left(3^{\text {rd }} \mathrm{ed}\right)$. London: Edward Arnold.

Halliday, M.A.K. \&Matthiessen. (2014).An Introduction to Functional Grammar (4 ${ }^{\text {th }}$ ed). London: Edward Arnold.

Halliday, M.A.K. (2009).The Essential. London: Continuum 
Jaya, I \& Daud, B.(2017).A Discourse Analysis of Melengkan at a Gayonese Wedding Ceremony.SIELE Studies in English Language and Education Journal.(Online).Vol.4 No.1 2017. Retrieved from http://jurnal.unsyiah.ac.id/SiELE/article/view/7008.

Joyce, Helen S \& Gaudin, J. (2007). Interpreting The Non verbal. Student Workbook, Australia: Phoenix Education

Kress, G. (1988).Communication and Culture: An Introduction. Kensington NSW: New South Wales University

Krees, G \& Leeuwen. (2001). Multimodal Discourse. The Modes and Media of Contemporary Communication. London: Arnold

Krees, G \& Leeuwen. (2006).Reading Images. London: Routledge.

Matthiessen. C, Teruya. K \& Lam. M. (2010).Key Term in Systemic Functional Linguistics.London: Continuum.

Miles, M.B and Huberman, A.M. (1994).Qualitative Data Analysis.London: SAGE Publication

Miles, Matthew B., A. Michael Huberman\& Johnny Saldana. (2014).Qualitative Data Analysis: A Method s Source book. ( $3^{\text {rd }}$ ed). America: Sage Publication.

Milner. A. (2002).Re-Imagining Cultural Studies. London: SAGE Publication

O’Halloran, K.L. (2004). Multimodal Discourse Analysis.System Functional Perspectives. London: Continuum.

O’Halloran, K.L. (2006). Multimodal Discourse Analysis.System Functional Perspectives. London: Continuum.

Rahmah., Sinar, T. S., Meko, A. M \& Eddy. S. (2015). Ideational Meaning of Wedding Ceremonyin Deli Malay's Traditional Culture: A Multimodal Analysis. IOSR Journal Of Humanities And Social Science

(IOSR-JHSS), (Online), Vol. 20, Issue2, Ver.1. Retrieved from http://www.iosrjournals.org/iosr-jhss/papers/Vol20issue2/Version-1/E020212229.pdf

Rohmana, F \& Ismail, T. (2013).Consumption Ritual In Javanese Wedding Ceremony: Ethnography Research In Kabupaten Ngaw1. Asia-Pacific Management and Business Application Brawijaya University Journal, (Online), Vol.2 No 1. Retrieved from http://apmba.ub.ac.id/index.php/apmba/article/view/151.

Robertson. R. (1977).Eisenstein on The Audionon verbal.King's College: London.

Rusalic. D. (2009). Making The Intangible Tangible. Belgrade

Trompenaars. F, Turner. C.H. (1997). Riding the Waves of Culture ( $2^{\text {nd }}$ ed $)$. London: Nicholas Brealey

Unsworth, L. (2008). Multimodal Semiotics. London: Continuum.

Young. L, Harrison.C. (2004). Systemic Functional Grammar and Critical Discourse Analysis.London: Continuum. 